\title{
MEDIA LITERACY TRAINING FOR SENIOR HIGH SCHOOL STUDENTS IN MEDAN CITY
}

\author{
Mazdalifah $^{1)}$, Fatma Wardy Lubis ${ }^{2)}$, Yovita Sabarina Sitepu ${ }^{3)}$ \\ ${ }^{1)}$ Faculty of Social and Political Sciences University of Sumatera Utara \\ Email: mazdalifah@usu.ac.id \\ ${ }^{2)}$ Faculty of Social and Political Sciences University of Sumatera Utara \\ Email: mazdalifah@usu.ac.id \\ ${ }^{3)}$ Faculty of Social and Political Sciences University of Sumatera Utara \\ Email: mazdalifah@usu.ac.id
}

\begin{abstract}
The phenomenon of internet use, especially social media among teenagers in high school students shows an increase. Some cases show up such as: cyberbullying, trafficking, hoaxes and hate speech. The purpose of community service is to prepared high school students have knowledge and skills in internet media literacy, especially social media. The training participants numbered 42 people, consisting of: SMA N 1, SMA N 2, SMA Harapan Mandiri, SMA Harapan 3, and SMA Bimsa Medan. Form of community service activities by mapping problems through Focus Group Discussion (FGD). Then do the training for two days. The results of the FGD and Seminar shows that the use of the internet, especially social media, includes a very high category of six hours per day. The most widely accessed social media are Instagram and Whatsapp. The purpose they access is to find out information about friends, celebrities, and activities / events that happening around them. Generally high school students have made efforts to choose good media content and avoid bad content, such as violence and pornography. High school students try to read messages on social media well and think about what will be written. They do things like this to avoid the law as stated in the Indonesia ITE Law.
\end{abstract}

Keywords: Training, media literacy, internet, high school students

\section{INTRODUCTION}

\subsection{Situation Analysis}

The growth of science has encouraged the development of communication technology. Increasingly sophisticated technology has produced new internet media. These media has many forms, such as: social networking (Facebook, Twitter, Instagram), social media (Line Messenger, WhatsApp, etc.), e-mail, information search engines (Google), online games, which are used by the public as a place to find and integrate information using resources available on the internet. In addition to providing benefits, the internet can also causes disadvantages. This happens because through the internet, people can access negative content such as violence and pornography, especially the presence of smartphone that can easily access content anywhere.

Nowadays young generation are very familiar with the internet and online games. They can access on their personal computer, laptop, smartphone and even in internet cafes. They are known as the generation of digital natives because they was born, grew and developed in the digital era. They access and have skills regarding the internet beyond the previous generation. The younger generation, especially teenager, access the internet to help complete school assignments, find other knowledge sources, even to find scholarships. However, there are also many problems when young people use the internet without supervision.

This kind of phenomenon if left continuously it will bring many problems. This is related to negative content 
(violence and pornography), and includes addictive (addicted) in using the internet. Some occasion of human trafficking or cyberbullies often appeared in newspaper and this also afflict several young generation especially for teenagers. Abduction cases that occur in young women, starting with contacts on social media. They did not realize that exposing their identities openly on social media made them have the potential to become the basis of kidnapping and human trafficking, which is known as human trafficking.

Younger generation especially teenagers, they access many violent videos or online games on the internet. Many of uploaded videos contain violence that can be accessed by teenagers anytime, so it is feared that if they often saw the content of violence it will cause them to regard a violence as normal. Similarly with pornographic content, even though there have been preventative efforts from Ministry of Communication and Information Technology (KEMKOMINFO) in order to limit pornographic content, there's still has some sites can be easily accessible. If this information flow while there is no serious effort to control it, it will have a negative impact on the young generation.

Besides that, online experiences in a certain times can be expanded and plunge someone to ignore the real world. When someone till the extreme level while using the internet, it called internet addiction. This is can be happen to smart and sociable students that can turn 180 degrees because they are more interested life in cyberspace than in real life. This situation lead someone to see their life's experience as a true part of their life.

The newest and just being discussed was about online games Pokemon Go that hit the world, including Indonesia. This augmented reality game is interesting because the players are driven to catch Pokemon characters whose location is adapted to the real world. When someone is too focused on their screen with a Pokemon inside it seems that their awareness of surrounding environment is lost.

A way to educate public that allow people to access, critically evaluate especially the internet are known as media literacy. This activity needs to be carried out primarily in schools and is aimed at children and adolescents who are still studying. Media literacy is the ability of the public to understand, evaluate, choose and produce media messages.

\subsection{Partner Problems}

1. Lack of knowledge of the younger generation especially high school students about the bad influence of the internet.

2. Lack of ability of the younger generation especially high school students to sort out internet content, especially negative content such as violence, pornographic, cyberbullying, and trafficking.

3. Lack of skills in packaging interesting and positive messages on the internet especially social media.

\subsection{Purpose and The Virtue of Devotion}

1. Knowledge and skills for the younger generation about the internet especially about the bad influences of the internet.

2. Skills in sorting internet content to avoid negative content such as violence and pornography.

3. Skills in packing interesting and positive messages on the internet, especially social media, so that they can avoid of the target trafficking and cyberbullying.

As for the main features of community service activities are:

1. The young generation, especially high school students, have knowledge of the good and bad influences of the internet.

2. The younger generation, especially high school students, have the skills to sort out internet content, especially negative content.

3 . The younger generation especially high school students have the skills to 
package interesting and positive messages on social media.

\section{SOLUTION AND EXTERNAL TARGET}

\subsection{Service / Devotion Solution}

The solutions offered by researchers are as follows: Providing insight about the Internet, Generation (Twitter / Facebook / Google / Instagram / Netflix / Tumblr / Path). Carry out application selection practice that related to the negative content, such as violence, pornographic, cyberbullying and human trafficking. The practice of selecting applications related to positive content and the practice of packaging web content messages through training both during training and monitoring.

\subsection{Output Target}

\begin{tabular}{|l|l|l|}
\hline No. & $\begin{array}{l}\text { Type of } \\
\text { Output }\end{array}$ & $\begin{array}{l}\text { Indicators of } \\
\text { Achievement }\end{array}$ \\
\hline 1. & $\begin{array}{l}\text { Scientific ic } \\
\text { publication in } \\
\text { journal / } \\
\text { proceedings }\end{array}$ & Accepted \\
\hline 2. & $\begin{array}{l}\text { Publication in } \\
\text { mass media } \\
\text { (print media, } \\
\text { electronic, } \\
\text { and online } \\
\text { media) }\end{array}$ & Contained \\
\hline 3. & $\begin{array}{l}\text { Increasing } \\
\text { community } \\
\text { knowledge } \\
\text { and skills }\end{array}$ & Exist \\
\hline
\end{tabular}

\section{IMPLEMENTATION METHOD}

\subsection{Approach Method}

This study is uses an approach method by carrying out the first stage of conducting need assessment through the Focus Group
Discussion (FGD) method to the target audience, high school students in Medan City. Furthermore, after knowing the needs and problems then determine the goals to be achieved. Based on this goal, a training activity consisting of 40 high school / vocational students was held. Training is carried out with participatory methods that applied adult education (andragogy).

\subsection{Partner Participation in Program Implementation}

The partners in the implementation of this program are Senior High Schools (SLTA) in the Medan City area which consist of high school and vocational schools both public and private. Then they provide advice on the implementation of activities and participate in the process of evaluating and monitoring the service activities of the participants.

\subsection{Evaluation of Program Implementation and Sustainability}

Evaluation of program implementation was carry out during training. This evaluation was carried out by distributing questionnaires containing an assessment of training materials (the adequacy of the material, the ease of material understood). Submission of training material, training time, training venue, and consumption during training.

Program sustainability. The proponents of the service and school activities will hold meetings together with students to discuss the sustainability of the programs in their respective schools.

\section{RESULTS AND OUTCOMES ACHIEVED}

The series of activities were held on $4^{\text {th }}$, $10^{\text {th }}$ and $11^{\text {th }}$ July 2018 , located in the USU FISIP Multifunction Hall. The service activities are divided into two forms, Focus Group Discussion and Training. The training was conducted for two days. The 
FGD activities was held on July $4^{\text {th }}, 2018$ were attended by 30 high school students from five schools. The school that sent students to took a part in the FGD was SMA N 1, SMA N 2, SMA Harapan Mandiri, SMA Harapan 3, and SMA Bimsa Medan.

In this activity, students must be active on giving information about their habits and their insight in using the internet, especially social media. From the discussion that carried out by the service team, Yovita Sabarina Sitepu, obtained some important information as a general description of teenage consumption patterns on social media. Discussion were followed a list of questions that had been prepared by the previous team to make the discussion more focused so that the team can compile and collect information obtained neatly.

Furthermore, conducting media literacy training was carried out for two days attended by 42 students. The school that sent students to attend the training was SMA N 1, SMA N 2, SMA Harapan Mandiri, SMA Harapan 3, and SMA Bimsa Medan. Some trainees were also participants in the previous week FGD activities.

In this training the topic presented was follow as: negative positive media content, selecting and sorting media content, how to messages packing on social media, and the training series closed with the explanation of communication skills topic.

\section{NEXT STAGE PLAN}

The FGD activities that have been carried out provide much information about the habits and patterns of consumption social media in adolescents (teenagers), especially high school students in Medan city. The training is one step to spread awareness of the using social media among adolescents. Reports on media literacy training activities need to be published further in order to transmit the same action in other environments.

\section{CONCLUSIONS}

\section{RECCOMENDATIONS}

AND

These community service activities with the title "Media Literacy Training for Senior High School Students in Medan city" are expected to produce young generation who have knowledge of the good and bad influences of the internet.

The FGD, discussion and training will hone students' skills in sorting out the content on the internet, especially negative contexts. Besides that the training provided can make students able to package interesting and positive messages on social media.

This kind of training should be carried out continuously for other students in North Sumatra. This Media literacy training will make students smarter in using social media / internet. In addition, the upcoming service activities are expected to produce an "Internet media Literacy Module" aimed at the younger generation, especially high school students. This module will be a guide for individuals or institutions that will conduct similar training.

\section{ACKNOWLEDGMENTS}

Thank you to those who have helped both substantially and financially. To the Chancellor of the University of Sumatera Utara (USU) through the Community Service Agency (LPM) USU has assisted through USU Non-PNBP funds in 2018

\section{REFERENCES}

Biagi, Shirley. (2010). Media Impact Pengantar Media Massa. Jakarta: Salemba Humanika

Hastuti Nur Rochimah, Tri., \& Junaedi, Fajar. (2013). Media Parenting: Panduan Memilih Media Bagi Anak di Era Informasi. Yogyakarta: Buku Litera. 
Subandi Ibrahim, Idi., \& Ali Ahmad, Bachrudiin. (2014). Komunikasi dan Komodifikasi Mengkaji Media dan Budaya dalam Dinamika Globalisasi. Jakarta: Yayasan Pustaka.

Taburaka, Apriadi. (2013). Literasi Media Cerdas Bermedia Khalayak Media Massa. Jakarta: Raja Grafindo Persada.

Tim Kajian YPMA. (2011). Memahami Interaksi Remaja dengan Internet. Jakarta: Yayasan Pengembangan Media Anak.

Tim Peneliti PKMBP. (2013). Model-Model Gerakan Literasi Media dan Pemantauan Media di Indonesia. Yogyakarta: PKMB dan Yayasan TIFA.

Tesis

Yolanda, Eninta. (2015). Peran Facebook dan Instagram Komunitas Backpacker Medan dalam Mendukung Pariwisata di Sumatera Utara. Medan: Fakultas Ilmu Sosial dan Ilmu Politik.

Surat Kabar

Harian Kompas, Panas Dingin Pokemon, 23 Juli 2016

Internet

https://kominfo.go.id $>$ berita_satker, Pengguna Internet di Indonesia capai 82 juta.

m.liputan6.com>Internet, 3 Fakta Mengejutkan Pengguna Internet di Indonesia. 